PRINT ISSN 1119-8362

Electronic ISSN 1119-8362
Full-text Available Online at

https://www.ajol.info/index.php/jasem

http://ww.bioline.org.br/ja
J. Appl. Sci. Environ. Manage.

Vol. 25 (8) 1341-1348 August 2021

\title{
Heavy Metals and Physicochemical Parameters Evaluation in the Upper Reaches of Bonny River, Niger Delta, Nigeria
}

\author{
AKANKALI, JA; *DAVIES, IC
}

Department of Fisheries, Faculty of Agriculture, University of Port Harcourt P.M.B. 2332, Choba, Port Harcourt, Rivers state, Nigeria

*Corresponding Author Email: davies.chris@uniport.edu.ng

\begin{abstract}
The objectives of the study were to determine distribution of heavy metal contamination in water, sediments and biota (Callinectes amniciola) of the upper reaches of the Bonny Estuary and to determine the impact on physicochemical characteristics of the water body. Sampled was from January to June 2020. The physicochemical parameters of the water varied slightly across the months but were within FEPA/WHO (2003) acceptable limits. Furthermore; the study compared the seasonal variations and determination of Bio-accumulation Factor (BF) of C. amnicola with respect to sediment. The study site is a tidal creek that drains into the main Bonny River channel within Niger Delta, Nigeria. The sampled locations/stations include Trans-Amadi slaughter in Azuabie $\left\{\mathrm{N}^{\circ} 81^{\prime} 49.9\right.$ and E7 $\left.04^{\prime} 63.4\right\}$, Okpoka Creek in Abuloma $\left\{\mathrm{N}^{\circ} 78^{\prime} 02.43\right.$ and $\left.\mathrm{E} 7^{\circ} 06^{\prime} 66.12\right\}$ and Okirika Jetty $\left\{\mathrm{N} 4^{\circ} 73^{\prime} 70.04\right.$ and $\left.\mathrm{E} 7^{\circ} 09^{\prime} 56.93\right\}$. Samples of surface water, sediments and swimming crabs were collected from three different stations which were at least 1000 meters apart. The results of this study show that concentrations of the heavy metals ( $\mathrm{Fe}$ and $\mathrm{Zn}$ ) were both higher in the three media than the approved limits prescribed by the local regulatory authority. Although $\mathrm{Cu}$ was relatively within acceptable limit in the three media. There is therefore the need to control the anthropogenic activities within or around the river. This will help to prevent effluent and solid waste discharges that lead to increase in the concentration of heavy metals in the aquatic environment. Routine monitoring should be encouraged to identify the major sources of heavy metals introduction into the river and their impacts on the aquatic resources.
\end{abstract}

DOI: https://dx.doi.org/10.4314/jasem.v25i8.1

Copyright: Copyright $\odot 2021$ Akankali and Davies. This is an open access article distributed under the Creative Commons Attribution License (CCL), which permits unrestricted use, distribution, and reproduction in any medium, provided the original work is properly cited.

Dates: Received: 10 May 2021; Revised: 28 June 2021; Accepted: 01 July 2021

Keywords: Heavy metals, Bonny River, C. amnicola, Surface water and Sediment

Globally, Water pollution has become a cause for worry (Miebaka, 2017). Water which is important and essential has been impaired by pollution from natural and anthropogenic sources. This has reduced the quality and the productivity of aquatic ecosystems (Abdel-Baki et al., 2013). Similarly, FAO, 1992 reported that one of major sources of these pollutes which reduces the quality of water are the heavy metals. Naturally, heavy metals are present in aquatic ecosystems but are present in low concentration (Akankali et al., 2019). Their source is from the earth crust and they cannot be easily destroyed or degraded (Jaishankar et al., 2014). The natural levels of heavy metals can be exceeded due to human activities such as industrial activities, agricultural activities, increase in urbanization exploration and exploitation of natural resources (Nongnud et al., 2003). In recent times, aquatic environmental pollution with heavy metals has become a problem worldwide because they are indestructible and most of them are toxic and have potential effect on the aquatic environment (Ozturk et al., 2009). The toxicity effects of these heavy metals on the aquatic organisms and its environment can be direct or indirect and can impact on the aquatic ecosystem, its population and humans. Heavy metals toxicity causes genetic aberrations in fish which could lead to impaired growth, deformation of embryo and affect fry development and increased the level of mortality (Akankali and Davies, 2018).

The swimming crabs (Callinectes amnicola) is food organism that has strong flattened legs, sharp claws that makes them fast and aggressive predators and paddle shape that aids swimming. They are very important fish food that can be caught in the coastal fishery and Lagoons in West Africa (Davies et al., 2006). The Bonny estuary is an aquatic resource in the Southern part of the Niger Delta, Nigeria. It is an estuarine environment that receives domestic, municipal, sewage and industrial wastes discharged by coastline and urban dwellers as well as industries activities around the Trans-Amadi Industrial layout in Port Harcourt city, Nigeria (Erema and Miebaka, 2013). This study is therefore conducted to determine the levels of some selected heavy metals in the $C$. amnicola (swimming crab), water and sediment of the upper reaches of the Bonny River at different sample sits. 


\section{MATERIALS AND METHODS}

Study site: The sampling stations were at least 1,000 meters apart along the upper reaches of the Bonny River. The sampling stations were geo-referenced and selected specifically to cover areas of the river receiving effluents and wastes form different anthropogenic activities of the area; Okrika Jetty \{Station 1: N4 ${ }^{\circ} 73^{\prime} 70.04$ and E7 ${ }^{\circ} 09^{\prime} 56.93$, Okpoka Creek in Abuloma \{Stations 2: N4 ${ }^{\circ} 78^{\prime} 02.43$ and $\left.\mathrm{E}^{\circ}{ }^{\circ} 06^{\prime} 66.12\right\}$ and Trans-Amadi slaughter in Azuabie \{Stations 3: N4 $81^{\prime} 49.9$ and $\left.\mathrm{E}^{\circ} 04^{\prime} 63.4\right\}$. Figure 1 shows map of the study area with the various sampling stations. The upper Bonny estuary is an aquatic resource of immense fisheries and socio-economic importance. This section of the river is utilized by residents for artisanal fishing, while various water related activities such as commercial water transportation, industrial/manufacturing activities and oil and gas logistics operations are equally deployed either within or on the shores of this section of Bonny River. This scenario of the River hosting numerous anthropogenic activities results in wastes and effluents that pollute the river constantly.

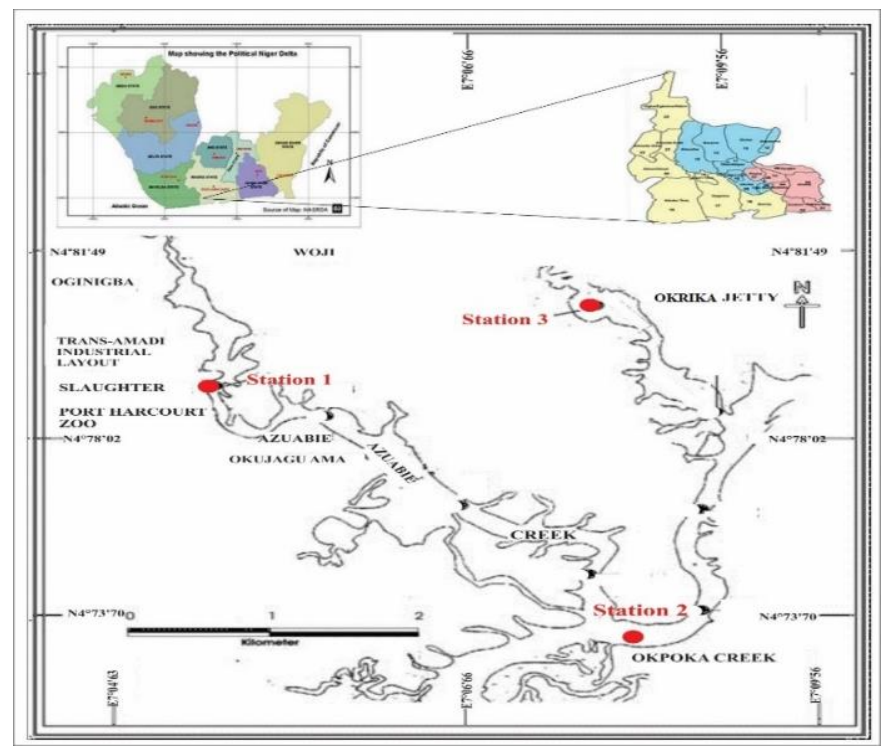

Fig 1: Map showing the study Area along the Azuabie Creek in Rivers state

Sampling methods: The Physicochemical Parameters such as $\mathrm{pH}$, temperature, salinity, total suspended solids (TSS) of the water were measured in-situ using Laboratory Bench-top meter (860033 model) while the Dissolved Oxygen (DO) was measured using Winkler's method. A composite sampling technique was used in the different sampling stations along the creek. The sediments were collected using an 'Ekman grab' sampler, while the surface water samples were collected in pre-cleaned high-density Schott glass bottles and the swimming crabs were collected using locally made fishing net traps and stored in an ice pack in the field to maintain the freshness and then transported to the laboratory, where they were stored at $10^{\circ} \mathrm{C}$ until analysis. After thawing, the midgut gland or hepatopancreas tissue was dissected and homogenized. The hepatopancreas was chosen for metal analysis because it is an organ which sequesters metals and would therefore provide an integration of metal contaminant exposure over time, free from the confounding effects of frequent molting (MacFarlane, 2000). The different sampled media of the upper Bonny River for which heavy metals (Iron, Zinc and
Copper) were analyzed using standard laboratory procedures (Atomic Absorption Spectrophotometric Machine (API-RP 45) include surface water, sediment and $C$. amnicola (Plates 1 to 4 ). Sampling was carried out once a month for six months from January to June 2020 based on the Bonny River tide table.

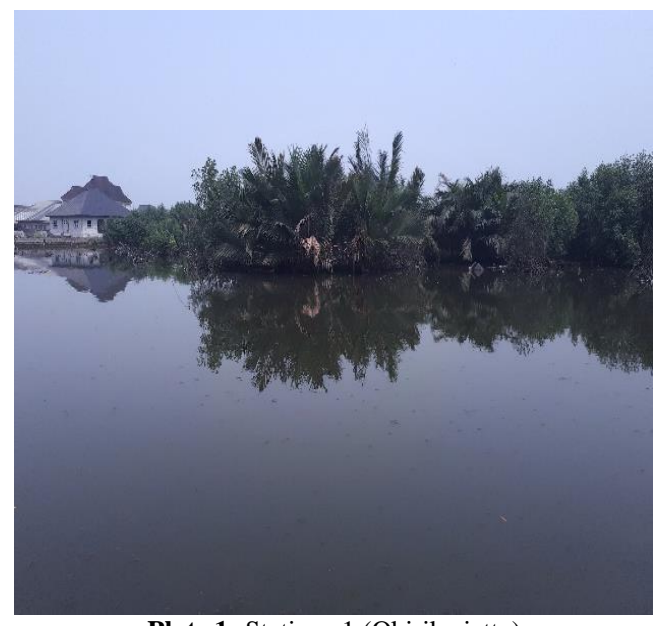

Plate 1: Stations 1 (Okirika jetty) 


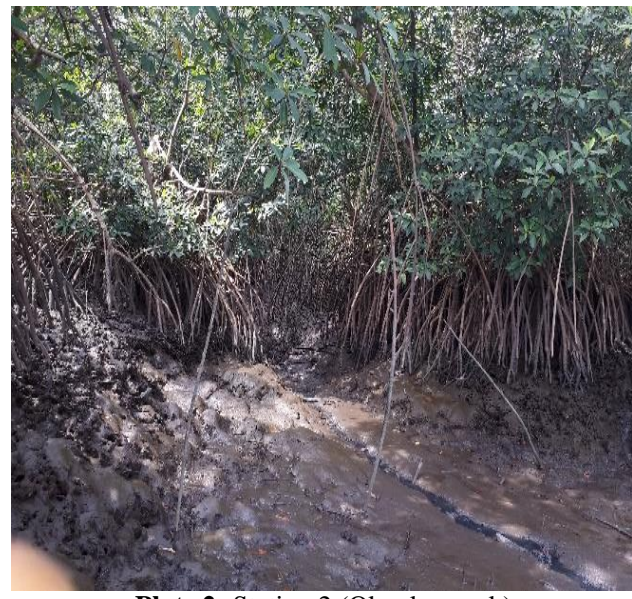

Plate 2: Station 2 (Okpoka creek)

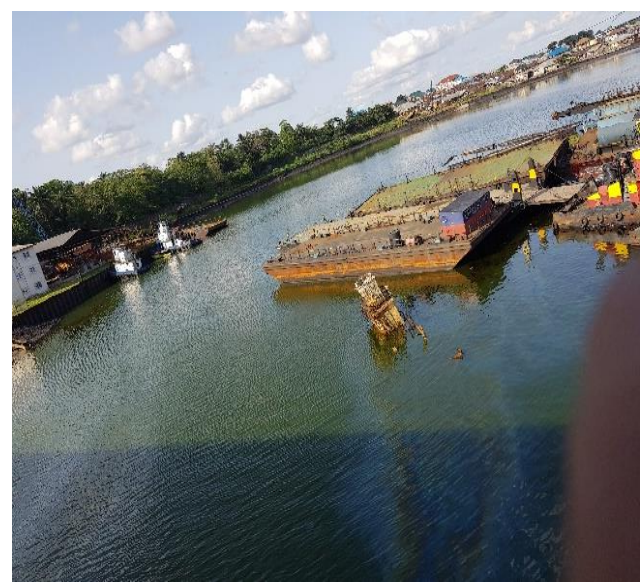

Plate 3: Station 3 (Azuabie creek)

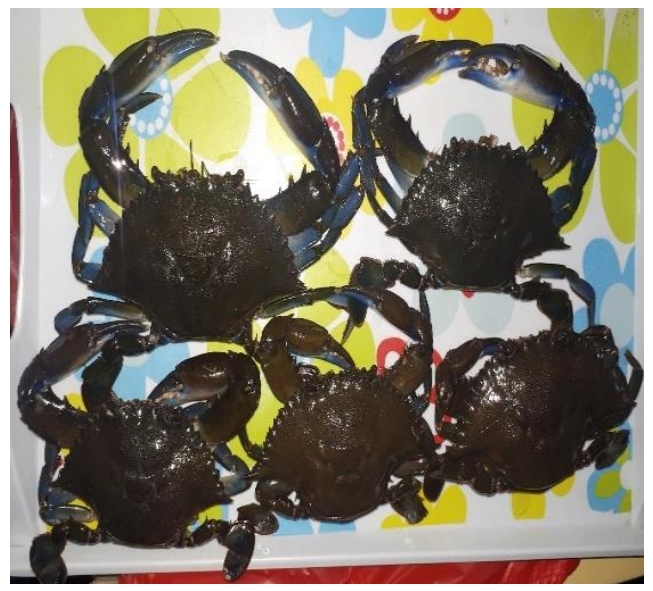

Plate 4: Callinectes amnicola (Swimming Crab)

A comparative analysis of the levels of these three metals in water, sediment and selected biota was carried out to determine the extent of heavy metal concentrations in them using the Atomic Absorption Spectrophotometric Machine (API-RP 45). Also, the Bioaccumulation Factor (BAF) was determined; BAF $=$ Concentration of metals in fishes $(\mathrm{mg} / \mathrm{L})$
/Concentration of metals in sediments.

Statistical Analysis: The results were subjected to oneway Analysis of variance (ANOVA) was performed to compare the means and the statistical significance was considered for $\mathrm{p}<0.05$.

\section{RESULTS AND DISCUSSION}

Physicochemical Parameters: The mean values of the physicochemical parameters are presented in table 1 .

Temperature: The temperatures recorded for maximum and minimum values were $29.3 \pm 0.05^{\circ} \mathrm{C}$ and $27.0 \pm 0.05^{\circ} \mathrm{C}$ during the dry season and $28.2 \pm 0.20^{\circ} \mathrm{C}$ and $27.6 \pm 0.20^{\circ} \mathrm{C}$ during the wet season respectively. There was no significant difference $(\mathrm{P}>0.05)$ observed between the maximum and minimum values recorded in both the dry and wet season.

$p H$ : The $\mathrm{pH}$ value was maximum $7.3 \pm 0.05$ and minimum $6.42 \pm 0.05$ during the dry season and $7.0 \pm 0.05$ and $6.5 \pm 0.05$ during the wet season respectively. There were no significant differences $(\mathrm{P}>0.05)$ observed between the maximum values observed during the dry and wet season and no significant differences $(\mathrm{P}>0.05)$ was observed between the minimum values recorded during the dry and wet season.

Dissolved oxygen (DO): DO recorded maximum and minimum values during the dry season of $4.35 \pm$ $0.03 \mathrm{mg} / \mathrm{L}$ and $3.6 \pm 0.03 \mathrm{mg} / \mathrm{L}$ respectively, while the maximum and minimum values recorded during the wet season was $2.6 \pm 0.01 \mathrm{mg} / \mathrm{L}$ and $2.45 \pm 0.10 \mathrm{mg} / \mathrm{L}$ respectively. There were significant differences $(\mathrm{P}<0.05)$ observed between the maximum and minimum values recorded in both the wet and dry season.

Salinity: Salinity recorded maximum and minimum values of $134.2 \pm 0.05 p p t$ and $62.4 \pm 0.05$ ppt during the dry season and recorded the maximum and minimum values of $138.6 \pm 0.05 \mathrm{ppt}$ and $62.3 \pm 0.05 \mathrm{ppt}$ during the wet season respectively. There were significant differences $(\mathrm{P}<0.05)$ observed between the maximum values recorded during the dry and wet season, but there was no significant difference observed between the minimum values recorded during dry and wet season.

Total suspended solids (TSS): TSS recorded maximum and minimum values of $272 \pm 0.03 \mathrm{mg} / \mathrm{L}$ and $164 \pm 0.03$ $\mathrm{mg} / \mathrm{L}$ during the dry season and recorded the maximum and minimum values at $248.6 .7 \pm 0.003 \mathrm{mg} / \mathrm{L}$ and $143 \pm 0.03 \mathrm{mg} / \mathrm{L}$ during the wet season respectively. There were significant $(\mathrm{P}<0.05)$ differences observed between the maximum and 
minimum values recorded in both the wet and dry season.

Variations in Heavy Metals across the Various Media: Table 2 and Figure 2 show the variations of the heavy metals across the different media sampled between the months of January to June 2020. The results obtained for water, sediments and Swimming Crab are presented below:

Swimming Crab (Callinectes amnicola): In the Swimming crab, the maximum value of $\mathrm{Cu}$ observed for dry season was $0.21 \pm 0.01 \mu \mathrm{g} / \mathrm{g}$ and the minimum value was $0.15 \pm 0.01 \mu \mathrm{g} / \mathrm{g}$. The maximum value for wet season was $0.21 \pm 0.01$ and the minimum was 0.14 $\pm 0.01 \mu \mathrm{g} / \mathrm{g}$. There was no significant difference ( $>0.05)$ across the seasons for both dry and wet seasons. Zn recorded maximum value in dry season as $9.22 \pm 0.25 \mu \mathrm{g} / \mathrm{g}$ and minimum value $(4.45 \pm 0.25$ $\mu \mathrm{g} / \mathrm{g}$ ) in the wet. The maximum value for wet season was $9.44 \pm 0.24 \mu \mathrm{g} / \mathrm{g}$ and the minimum were $1.92 \pm 0.24 \mu \mathrm{g} / \mathrm{g}$. There was no significant difference ( $>0.05$ ) between maximum values in dry and wet seasons but there was significant difference $(\mathrm{p}<0.05)$ between minimum of dry and wet seasons. Fe had its maximum value in dry season as $10.67 \pm 0.47 \mu \mathrm{g} / \mathrm{g}$ and the minimum value as $7.05 \pm 0.47 \mu \mathrm{g} / \mathrm{g}$. The maximum value for wet season was $14.9 \pm 0.28 \mu \mathrm{g} / \mathrm{g}$ and the minimum value was $9.5 \pm 0.28 \mu \mathrm{g} / \mathrm{g}$. There was significant difference $(\mathrm{p}<0.05)$ between the maximum values of both dry and wet seasons and there was significant difference $(\mathrm{p}<0.05)$ between the minimum values of dry and wet seasons.

Sediment: Sediment recorded the maximum value of $\mathrm{Cu}$ in the dry season as $0.23 \pm 0.01 \mathrm{mg} / \mathrm{l}$ and the minimum value was $0.17 \pm 0.01 \mathrm{mg} / \mathrm{l}$. The maximum value for wet season was $0.33 \pm 0.01 \mathrm{mg} / \mathrm{l}$ and the minimum value was $0.21 \pm 0.01 \mathrm{mg} / \mathrm{l}$. There was significant difference $(\mathrm{p}<0.05)$ between the maximum values of the dry and wet seasons and there was significant difference $(\mathrm{p}<0.05)$ between the minimum values of dry and wet seasons. $\mathrm{Zn}$ had its maximum value in dry season as $7.39 \pm 0.24 \mathrm{mg} / \mathrm{l}$ and the minimum value as $2.83 \pm 0.24 \mathrm{mg} / \mathrm{l}$. It had its maximum value in wet season as $9.88 \pm 0.24 \mathrm{mg} / \mathrm{l}$ and minimum value as $3.79 \pm 0.24 \mathrm{mg} / \mathrm{l}$. There was significant difference $(\mathrm{p}<0.05)$ between maximum values of dry and wet seasons and there was significant difference $(\mathrm{p}<0.05)$ between the minimum values of the dry and wet seasons. Fe had its maximum value in dry season as $9.86 \pm 0.46 \mathrm{mg} / \mathrm{l}$ and the minimum value in dry season as $5.55 \pm 0.46 \mathrm{mg} / \mathrm{l}$. It had its maximum value in wet season as $14.07 \pm 0.28 \mathrm{mg} / \mathrm{l}$ and had its minimum as $9.11 \pm 0.28 \mathrm{mg} / \mathrm{l}$. There was significant difference $(\mathrm{p}<0.05)$ between the maximum values of dry and wet seasons and there was significant difference $(\mathrm{p}<0.05)$ between the minimum values of dry and wet seasons.

Table 1: Seasonal Variation (Dry and Wet Seasons) of Physicochemical Parameters from the Month of January to June 2020

\begin{tabular}{llllllll}
\hline Parameters & $\begin{array}{c}\text { Dry } \\
\text { season }\end{array}$ & $\begin{array}{l}\text { Wet } \\
\text { season }\end{array}$ & $\begin{array}{l}\text { Standard limit } \\
\text { (FEPA/WHO 2003) }\end{array}$ & & \\
\hline & Max & Min & S.E $( \pm)$ & Max & Min & S.E $( \pm)$ & \\
\hline Temperature & $29.3^{\mathrm{a}}$ & $27.0^{\mathrm{a}}$ & 0.2 & $28.2^{\mathrm{a}}$ & $26.9^{\mathrm{a}}$ & 0.20 & $27.8-30^{\circ} \mathrm{C}$ \\
pH & $7.3^{\mathrm{a}}$ & $6.42^{\mathrm{a}}$ & 0.05 & $7.0^{\mathrm{a}}$ & $6.5^{\mathrm{a}}$ & 0.05 & $6-9$ \\
Dissolved Oxygen & $4.35^{\mathrm{a}}$ & $3.6^{\mathrm{a}}$ & 0.01 & $2.6^{\mathrm{b}}$ & $2.45^{\mathrm{b}}$ & 0.01 & 20 \\
Salinity & $134.2^{\mathrm{b}}$ & $62.4^{\mathrm{b}}$ & 0.05 & $138.6^{\mathrm{a}}$ & $62.3^{\mathrm{a}}$ & 0.05 & - \\
Total Suspended Solids & $272^{\mathrm{a}}$ & $164^{\mathrm{a}}$ & 0.03 & $248.6^{\mathrm{b}}$ & $143^{\mathrm{b}}$ & 0.03 & 30 \\
\hline
\end{tabular}

*Along the rows, seasons with the same superscripts show no significant difference while stations with different superscript show significant difference

Table 2: Seasonal variation (dry and wet seasons) of heavy metals from the month of January to June 2020

\begin{tabular}{|c|c|c|c|c|c|c|c|c|}
\hline \multirow[t]{2}{*}{ Media } & \multicolumn{4}{|c|}{ Dry season } & \multicolumn{3}{|c|}{ Wet season } & \multirow[t]{2}{*}{ (WHO Spec.) } \\
\hline & \begin{tabular}{|l|} 
Heavy \\
Metals
\end{tabular} & $\begin{array}{l}\text { Max } \\
\mathrm{mg} / \mathrm{l}\end{array}$ & $\begin{array}{l}\text { Min } \\
\text { mg/l }\end{array}$ & $\mathbf{S ~ E}$ & $\begin{array}{l}\text { Max } \\
\text { mg/l }\end{array}$ & $\begin{array}{l}\text { Min } \\
\text { mg/l }\end{array}$ & SE & \\
\hline \multirow[t]{3}{*}{ C. amnicola } & $\mathrm{Cu}$ & $0.21^{\mathrm{a}}$ & $0.15^{\mathrm{a}}$ & 0.01 & $0.21^{\mathrm{a}}$ & $0.14^{\mathrm{a}}$ & 0.01 & 2.000 \\
\hline & $\mathbf{Z n}$ & $9.22^{\mathrm{a}}$ & $4.45^{\mathrm{a}}$ & 0.25 & $9.44^{\mathrm{a}}$ & $1.92^{\mathrm{b}}$ & 0.24 & 3.000 \\
\hline & $\mathrm{Fe}$ & $10.67^{b}$ & $7.05^{\mathrm{b}}$ & 0.47 & $14.9^{\mathrm{a}}$ & $9.5^{\mathrm{a}}$ & 0.28 & $0.5-50$ \\
\hline \multirow[t]{3}{*}{ Sediment } & $\mathrm{Cu}$ & $0.23^{\mathrm{b}}$ & $0.17^{\mathrm{b}}$ & 0.01 & $0.33^{\mathrm{a}}$ & $0.21^{\mathrm{a}}$ & 0.01 & 2.000 \\
\hline & $\mathbf{Z n}$ & $7.39^{\mathrm{b}}$ & $2.83^{\mathrm{b}}$ & 0.24 & $9.88^{\mathrm{a}}$ & $3.79^{\mathrm{a}}$ & 0.24 & 3.000 \\
\hline & $\mathrm{Fe}$ & $9.86^{\mathrm{b}}$ & $5.55^{\mathrm{b}}$ & 0.46 & $14.07^{\mathrm{a}}$ & $9.11^{\mathrm{a}}$ & 0.28 & $0.5-50$ \\
\hline \multirow[t]{3}{*}{ Surface water } & $\mathrm{Cu}$ & $0.15^{\mathrm{a}}$ & $0.13^{\mathrm{b}}$ & 0.01 & $0.16^{\mathrm{a}}$ & $0.11^{\mathrm{b}}$ & 0.01 & 2.000 \\
\hline & $\mathbf{Z n}$ & $5.73^{\mathrm{b}}$ & $2.67^{\mathrm{a}}$ & 0.24 & $6.73^{\mathrm{a}}$ & $1.89^{\mathrm{b}}$ & 0.24 & 3.000 \\
\hline & $\mathrm{Fe}$ & $8.27^{\mathrm{a}}$ & $5.33^{\mathrm{a}}$ & 0.46 & $7.70^{\mathrm{b}}$ & $4.87^{\mathrm{b}}$ & 0.28 & $0.5-50$ \\
\hline
\end{tabular}

*Along the rows, seasons with the same superscripts show no significant difference while stations with different superscript show significant difference 


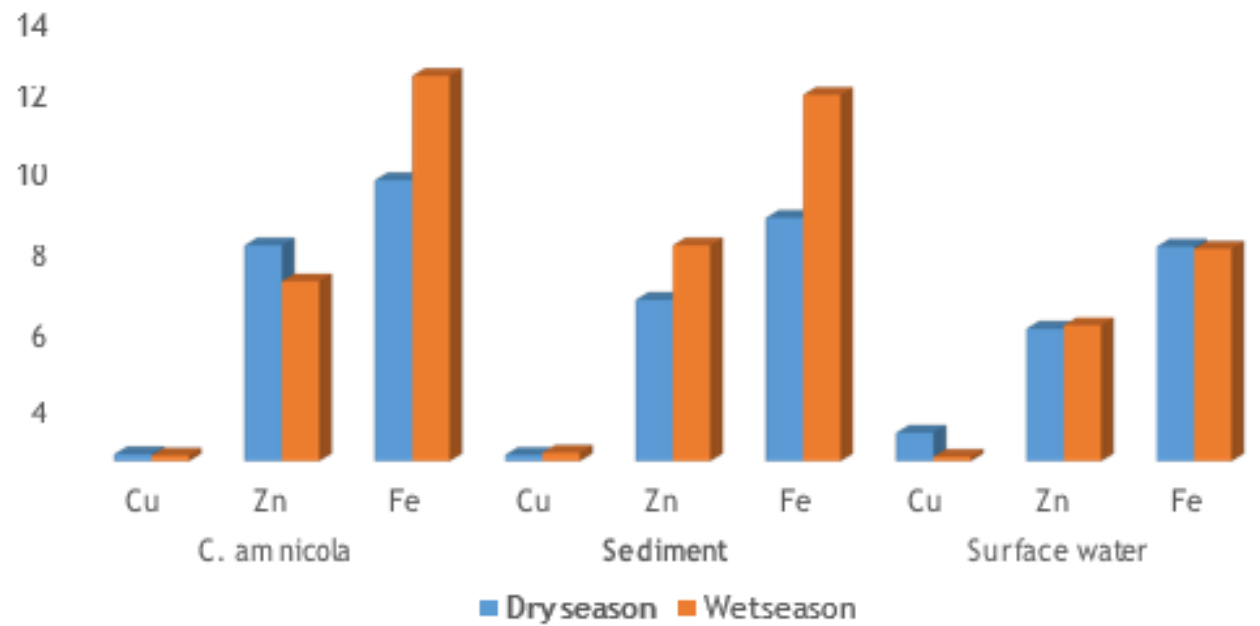

Fig 2: Seasonal variation (dry and wet seasons) of heavy metals Cross the months

Surface Water: The surface water recorded its maximum value of $\mathrm{Cu}$ in the dry season as $0.15 \pm$ $0.01 \mathrm{mg} / \mathrm{l}$ and its minimum value as $0.13 \pm 0.01 \mathrm{mg} / \mathrm{l}$. It had its maximum value in wet season as $0.16 \pm$ $0.01 \mathrm{mg} / \mathrm{l}$ and the minimum value was $0.11 \pm 0.01 \mathrm{mg} / \mathrm{l}$. There was no significant difference $(\mathrm{p}>0.05)$ between the maximum values of dry and wet seasons but there was significant difference between the minimum values of dry and wet seasons. $\mathrm{Zn}$ had its maximum value in dry season as $5.73 \pm 0.24 \mathrm{mg} / \mathrm{l}$ and its minimum value as $2.67 \pm 0.24 \mathrm{mg} / \mathrm{l}$. It had its maximum value in wet season as $6.73 \pm 0.24 \mathrm{mg} / \mathrm{l}$ and its minimum value as $1.89 \pm 0.24 \mathrm{mg} / \mathrm{l}$. There was significant difference between Surface water observed the maximum and minimum value of the maximum values of dry and wet seasons and there was significant difference $(\mathrm{p}<0.05)$ between the minimum values of dry and wet seasons. Fe had its maximum value in dry season as $8.27 \pm 0.46 \mathrm{mg} / \mathrm{l}$ and the minimum value as $5.33 \pm 0.46 \mathrm{mg} / \mathrm{l}$. It had its maximum value in wet season as $7.70 \pm 0.28 \mathrm{mg} / \mathrm{l}$ and its minimum value as $4.87 \pm 0.46 \mathrm{mg} / \mathrm{l}$. There was significant difference $(\mathrm{p}<0.05)$ between the maximum values of dry seasons.

Variations in Bioaccumulation Factor: Table 3 shows the bioaccumulation factor for the different metal across wet and dry season. $\mathrm{Cu}$ recorded a low bioaccumulation during the dry season at 0.91 than during the wet season at 0.70 . Both seasons had a BAF $<1$, which implies that $\mathrm{Cu}$ is an excluder across both seasons. Zn was more bio-accumulated in the dry season (1.59) and least during the wet season (0.82). it shows that $\mathrm{Zn}$ was more accumulated in the dry season than in the wet. The BAF in Fe was the higher in the dry season (1.11) and lower for the wet season (1.02). Both seasons had a BAF>1, which implies that Fe was an accumulator for both the dry and the wet season.
Table 3: Bio-accumulation factor in C. amnicola

Bio-accumulation factor

Metal Dry season Wet season

$\begin{array}{lll}\text { Cu } & 0.91 \quad 0.70\end{array}$

Zn $\quad 1.59 \quad 0.82$

Fe $\quad 1.11 \quad 1.02$

*When the value of the metal is $<1$, it implies that they are excluders, when the metals are $>1$, it implies that they are accumulators and when they are $=1$, it implies that they have no influence.

Physicochemical Parameters: Water temperature is an important parameter because it plays an important role in determining chemical reaction rates within the water body. The temperature values were highest in the dry season ranging from $27.0^{\circ} \mathrm{C}$ to $29.3^{\circ} \mathrm{C}$ and the lowest in the wet season at values ranging from $28.2^{\circ} \mathrm{C}$ to $28.2^{\circ} \mathrm{C}$. This result agrees with Hart and Zabbey (2005) of 27 to $28^{\circ} \mathrm{C}$ from some creeks of the Niger Delta. It also agrees with findings by Akankali and Davies (2018) who also reported temperature values of $26.7^{\circ} \mathrm{C}$ to $27.18^{\circ} \mathrm{C}$. The seasonal variation with higher dry season value than the wet season also agrees with Akpan and Offem (1993). This is also similar to the observation value $\left(27.3^{\circ} \mathrm{C}\right.$ to $\left.29.1^{\circ} \mathrm{C}\right)$ reported by Chindah and Braide (2004) for the Elechi creek The range of $\mathrm{pH}$ obtained between the dry and wet season varies slightly across months but where within FEPA/WHO (2003) acceptable limits. The slight fluctuation in $\mathrm{pH}$ values could be attributed to effluent discharge during the both seasons. This scenario could also be attributed to several sources of water such as rain water runoff that made their ways into the river thereby, increasing the level of fluctuation. The variations observed in this study is in conformity with the works of Akankali et al. (2019) who reported similar $\mathrm{pH}$ values during the dry season and lowest values during the wet season in the upper reaches of the Bonny River. The variations observed in this study is in conformity with the works of Erema 
and Miebaka (2013) who reported similar pH values (6.4-7.2) during the dry season and lowest values during the wet season in Azuabie creek. Dissolved oxygen (DO) is another important parameter that affects the survival of aquatic lives. DO values were higher in dry seasons with the highest mean value of $4.35 \pm 0.01 \mathrm{mg} / \mathrm{l}$ and lowest in the wet season with mean value of $2.45 \pm 0.01 \mathrm{mg} / \mathrm{l}$. Therefore, there was variation in DO along the sampling months which ranged from 2.45 to $4.35 \mathrm{mg} / \mathrm{l}$. This could be attributed to environmental factors (Akankali and Davies 2020). This was in line with DO levels that that were reported for a similar aquatic body (Estuary) and season within the Niger Delta region by Chindah (2004). However, there was a differing record by Ezekiel (2020), who reported that there were variations in DO levels along the sampled sites which ranged from $4.45 \pm 0.15$ to $6.15 \pm 0.15 \mathrm{mg} / \mathrm{l}$ in Trans-Woji stream of Trans-Amadi industrial area and in effluent channel from industries. Salinity is a measure of the total salt concentration which comprised mostly of $\mathrm{Na}^{+}$and $\mathrm{Cl}^{-}$ions and it is a total of all non-carbonate salts dissolved in water. Similar to other parameters, salinity varied across the months and ranged from 62.3 to $138.6 \pm 0.05 \mathrm{mg} / \mathrm{l}$ along the sampled sites as shown in table 1 . The highest salinity was recorded the dry season (138.6) while least values were recorded in the wet season $(62.3 \mathrm{mg} / \mathrm{l})$. This could be attributed to the levels of industrial effluents discharged into rivers which have been reported to be more significant during the dry season (Adekunle et al., 2009). Another justification for this trend of seasonal variation in salinity could be that the flow rates of the rivers were relatively lower in dry seasons as compared to the wet seasons, during which the volume of the water becomes higher in the rivers (Ezekiel 2020). The salinity differed from what was reported by Akankali et al. (2019) who observed highest in the dry season at values ranging from 61.7 to $147.3 \mathrm{ppt}$ and the lowest in the wet season at values ranging from 60.3 to $145.7 \mathrm{ppt}$. It could further be reasoned that increased volume of water during the rainy season often results in a more diluted salinity of water per given volume as against the dry season and not necessarily as a result of the increased level of salt content pollutants.

The total suspended solids (TSS) recorded the highest mean value in the dry season $(272 \pm 0.03 \mathrm{mg} / \mathrm{l})$ and the lowest values during the wet season $(164 \pm 0.03 \mathrm{mg} / \mathrm{l})$. These values exceeded the standard limits of FEPA/WHO (2003). This result differs from what was reported by Agarin et al., 2019 who observed considerable variations in the TSS values (1.00 and $48.00 \mathrm{mg} / \mathrm{l})$ recorded across the months sampled, with a mean value of $14.73 \pm 13.16$. The fluctuations could also be as a result of effluents from the sample sites which has led to an increase in the suspended solids (Agarin et al., 2019). The variation could also be attributed to physical, geological and biological processes around the sample station (Ekweozor et al., 2017). Ngah et al., 2017 also reported that variation in TSS could be attributed to the turbulent effect of excessive rains for which the Niger Delta is also known for. Thus, leading to significant variations in values of TSS between the months with differing precipitation values as was covered by this study.

Variations in The Heavy Metals in the Different Test Media: Heavy metals have different pathways through which it gets into the aquatic body. It could range from oxidation-reduction reactions, adsorption-desorption reactions, sedimentations re-suspensions and degrading organisms (Bakarat et al., 2012). Metals have been reported by many researchers as major pollutants of environmental concern which constitute hazardous substances that are non-degradable and has the ability to cause serious danger to aquatic life and its environment (Akankali and Davies, 2018). From the results, Iron $(\mathrm{Fe})$ consistently had the highest concentrations followed by Zinc (Zn) while Copper $(\mathrm{Cu})$ was the least in all the test media sampled across the six months with more in C. amnicola $(10.67 \mathrm{mg} / \mathrm{l})$ followed by the sediment $(9.86 \mathrm{mg} / \mathrm{l})$ and the least in the surface water $(8.27 \mathrm{mg} / \mathrm{l})$. This trend of variation can be attributed to the principles of bio-accumulation via absorption and adsorption (Adeleye et al., 2012). This could also be attributed to the fact that the intestine is potentially the most important organ for iron and zinc absorption (Gad and Saad, 2008). Although some organic pollutants may metabolize and break down rapidly in the intestine, water soluble pollutants will be excreted and other fat-soluble pollutants dissolve in fatty tissue of the fish (Qadir and Malik, 2011; Akankali and Davies 2018). The high concentration of Iron $(\mathrm{Fe})$ and Zinc $(\mathrm{Zn})$ recorded in C. amnicola as compared to the sediment and the water samples across the six months could be attributed to the fact that the $C$. amnicola are always found on the bottom of the water within the sediments during low tide, where it absorbs up more of the heavy metals as part of their food (Begum et al., 2009). This also agrees with Barakat et al. (2012), who reported that the metal concentrations found in water do not indicate the relative contributions of pollution because most of the metals are trapped, precipitated, settled and stored as pollutants in the sediments and has also bioaccumulated in the aquatic organisms.

Bio-Accumulation Factor: Bioaccumulation Factor value of $\mathrm{Zn}$ was highest during the dry season at 1.59 and was least during the wet season at 0.82 . The results from this study indicated that $\mathrm{Fe}$ and $\mathrm{Zn}$ 
bioaccumulated more in C. amnicola in the dry season than in the wet season. The study shows that $C$. amnicola and sediment accumulated more heavy metals than water. This could be attributed to the general held notion that sediment plays a role of main sink for most metals; with more than $99 \%$ of the sum amount of metals present in the aquatic system (Odiete, 1999) while the swimming crab (C. amnicola) is always found on the sediment during low tide where it takes up more of the heavy metals as part of its food (Abdul et al., 2009). This agrees with Eja et al., (2003); Chindah and Braide (2003). Bioaccumulation Factor values of $\mathrm{Zn}$ and $\mathrm{Fe}$ were found to be highest during the dry season at 1.59 and 1.11 and this implies that the Bioaccumulation Factor value was greater than 1 $(\mathrm{BAF}>1)$. Therefore, it implies that $\mathrm{Fe}$ and $\mathrm{Zn}$ were accumulators for both the dry and the wet season while $\mathrm{Cu}$ is an excluder across seasons, having a $\mathrm{BAF}<1$. However, low BAF could be attributed to assimilation and excretion rate of heavy metals in the organism examined (Moslen and Miebaka, 2017). There were significant spatiotemporal differences in the physicochemical parameters and heavy metal concentrations in both seasons. The variations in the concentration of $\mathrm{Fe}, \mathrm{Cu}$, and $\mathrm{Zn}$ explain the spatiotemporal changes of water body status. The spatiotemporal difference of water quality parameters may be mainly caused by the discharge of agricultural and domestic sewage around the sample sites (Hong et al., 2020) while the seasonal difference of heavy metal concentrations was caused by different degrees of human activity across the year. During flood season, the affected area with hanging river was seriously polluted and the pollutants may be accumulated mainly through natural factors (Cecilia et al., 2019).

The major routes by which metals are released into aquatic environment are industrial effluents, municipal and domestic sewage discharges, ship breaking and agriculture activities, exploration and production of oil/gas, and petroleum refinery etc. (Ra et al., 2014). Once metals incorporated into sediments, they are not readily available to aquatic habitats, but changes in physicochemical conditions like $\mathrm{pH}$, temperature, salinity, dissolved oxygen, total suspended solids and organic ligand concentrations can help dissolution of metals from a solid phase (Sharifuzzaman et al., 2016) Thus, environmental conditions of an area largely determine the bioavailability, mobility and toxicity of metals (Davies and Okonkwo, 2021)

Conclusion: The study established that the physicochemical parameters of the water varied slightly across the months but were within FEPA/WHO (2003) acceptable limits. However, the heavy metals concentrations were found to be highest in C. amnicola, with higher concentrations of $\mathrm{Fe}$ and $\mathrm{Zn}$ lesser concentration of $\mathrm{Cu}$ across the entire sampling duration. The values of Iron and Zinc across the threetest media were above the recommended limits of WHO/FEPA (2003). Therefore, the continuous discharge of these contaminated effluents and solid wastes into the Bonny River should be reduced to the barest minimum level.

\section{REFERENCES}

Abdel-Baki, A; Dkhil, M; Al-Quraishy, S (2013). Bioaccumulation of some heavy metals in tilapia fish relevant to their concentration in water and sediment of Wadi Hanifah, Saudi Arabia. Afr. J. of Biotechnol. 10(13), 2541-2547.

Adeleye, AO; Shelle, ROD; Akinnigbaghe, AE (2012). Pollutant dynamics and distribution in sediments North of Lagos lagoon ecosystem. Jr. of Nat. and Sci. 9(5):1316.

Adekunle, I. M., Olorundare, O., \& Nwange, C. (2009). Assessments of lead levels and daily intakes from green leafy vegetables of southwest Nigeria. Nutr. \& Fd. Sci. 39(4):413-422.

Abdul, RW; Wan, VL; Harun, A (2009). Accumulation and Depuration of Heavy Metals in the Hard Clam (Meretrix meretrix) under Laboratory Conditions; Tr. L. Sci. Res. 20(1):17-24.

Agarin, OJ; Davies, IC; Onyema, IC (2019). Evaluation of Some Physico-Chemical Parameters of the Tin Can Island Creek, Lagos, Nigeria. Nig. J. of Fr. 16 (2):17831793.

Akankali, JA; Davies, IC (2020). Analysis of heavy metals concentration in different media of Iwofe Creek, Niger Delta, Nigeria; Int. J. of Sci. and Res. Pub. 10(04): 22503153.

Akankali JA; Davies IC; Kpaniku, N (2019). Assessment of heavy metals concentrations in the upper reaches of Bonny River, Niger delta, Nigeria. Afr.J. of Agr. Technol and Environ. 8(1):62-73.

Akankali, JA; Davies, IC (2018). Assessment of heavy metal pollutants $(\mathrm{Zn} \& \mathrm{~Pb})$ in New Calabar River, Niger delta, Nigeria. Int. J. of Fr. and Aq. S. 6(2): 436-441.

Akpan, ER; \& Offem, JO (1993). Seasonal variation in water quality of the Cross River, Nigeria. Rev. hydr. Tro. 26(2):95-103.

Barakat A; Baghdadi, M; El Rais, J; Nadem, S (2012). Assessment of Heavy Metal in Surface Sediments of Day River at Beni-Mellal Region, Morocco. Res. J. of Environ. and Earth Sci. 4 (8):797-806. 
Begum A; HariKrishna, S; Khan, I (2009). Analysis of Heavy metals in Water, Sediments and Fish samples of Madivala Lakes of Bangalore, Karnataka: Int. J. of ChemTech. Res. 1(2):245-249.

Cecilia, R; Eduardo, Q; Vernica, M; Marion, P (2019). Evaluation of water quality and heavy metal concentrations in the RAMSAR Wetland El Yali (Central Chile, 33Åã450S). Ecol. Indic. 145. 499-507.

Chindah, AC (2003). The physico-chemistry, phytoplankton and periphyton of swan forest stream in the lower Niger, delta. Sci. Afric. 1(2): 1-15.

Chindah, AC; Braide, SA (2003). Cadmium and Lead concentrations in fish species of a brackish wetland / upper Bonny Estuary, Niger Delta. J. of Nig. Environ. Soc. 1(3):399-405.

Davies, IC; Okonkwo, SE (2021). Analyses of Some Heavy Metal and Nutrients of Water Samples from Ajegunle Creek in Lagos. Inter. J. of Environ. Pol. Res. 9(1):.7-26.

Davies, OA; Allison, ME; Uyi, HS (2006). Bioaccumulation of heavy metals in water, sediment and periwinkle (Tympanotonus fuscatus var rudula) from Elechi Creek, Niger Delta. Afr. J. of Biotechnol. 5(10):968-973.

Eja, ME; Ogri, ORA; Arikpo, GE (2003). Bioconcentration of heavy metals in surface sediments from the Great kwa Rivers Estuary, Calabar, South Eastern. Nig. J. Nig. Environ. Soc. (2): 247-256.

Ekweozor, IKE; Ugbomeh, AP; Ogbuehi, KA (2017) Zn, Pb, $\mathrm{Cr}$ and $\mathrm{Cd}$ concentrations in fish, water and sediment from the Azuabie Creek, Port Harcourt. J. of Ap. Sci. and Environ. Mang. 21(1): 87-91.

Parameters of Sediment from Azuabie Creek of the Upper Bonny Estuary, Niger Delta. ResJ. of Environ and Earth Sci. 5(4):219-228.

Ezekiel, EN (2020). Seasonal Variation of Physicochemical Parameters of Rivers Trans-Amadi, Port Harcourt, Rivers State. Eur. Acad.Res., 7(12):5949-5958.

FAO, 1992 African agriculture: the next 25 years. Atlas of African Agriculture. FAO, Rome, 72 pp.

FEPA (Federal Environmental Protection Agency) 2003. Guidelines and Standards for Environmental Pollution Control in Nigeria, Lagos, Nigeria.

Gad, NS; Saad, AS (2008). Effect of Environmental Pollution by Phenol on Some Physiological Parameters of Oreochromis niloticus: Global Veterinaria; 2(6):31231.

Hart, AI; and Zabbey, N (2005). Physico-chemical and benthic fauna of Woji Creek in the Lower

Niger Delta, Nigeria. Environ. Ecol. 23(2): 361- 368.
Hong, Z; Zhao, Q; Chang, J; Peng, L; Wang, S; Hong, Y; Ding, S (2020). Evaluation of water quality and heavy metals in wetlands along the Yellow River in Henan Province. Sust. 12(4), 1300.

Jaishankar, M; Tseten, T; Anbalagan, N; Mathew, BB; Beeregowda, KN (2014). Toxicity, mechanism and health effects of some heavy metals. Inter. Tox. 7(2), 6072 .

Miebaka, CA; Moslen, M (2017) Concentration of Heavy Metals and Health Risk Assessment of Consumption of Fish (Sarotherodon melanotheron) from an Estuarine Creek in the Niger Delta, Nigeria. J Env Sci, Toxicol Food Technol. 11, 68-73.

MacFarlane, GR; Booth, DJ; Brown, KR (2000). The semaphore crab, Heloecius cordiformis: bio-indication potential for heavy metals in estuarine systems. Aq. Tox. 50(3), 153-166.

Ngah, A; Braide, S; Dike, C (2017) Physico-Chemistry of Elechi Creek in the Upper Bonny Estuary, Rivers State, Nigeria. J. of Geosc. and Environ. Prot. 5, 181-197.

Nongnud, T; Poptipal, J; Helander. HF (2015) Distribution of heavy metals in sediments of the River Basin of coastal area of Chanthaburi Province Gulf of Thailand. Environ. As. 8(1).

Odiete, WO (1999). Environmental Physiology of animals and pollution Diversified Resources Ltd Lagos. 261pp.

Öztürk, M; Özözen, G; Minareci, O; Minareci, E (2009). Determination of heavy metals in fish, water and sediments of Avsar Dam Lake in Turkey. J. of Environ. Health Sci \& Eng. 6(2):73-80.

Qadir, A; Malik, RN (2011). Heavy metals in eight edible fish species from two polluted tributaries (Aik and Palkhu) of the River Chenab, Pakistan. Bio. Tr. El. Res. 14(3):1524-1540.

Ra, K; Kim, JK; Hong, S.H; Yim, UH; Shim, WJ; Lee, SY; Kim, KT (2014). Assessment of pollution and ecological risk of heavy metals in the surface sediments of Ulsan Bay, Korea. Ocean. Sci. J. 49(3), 279-289.

Sharifuzzaman, SM; Rahman, H; Ashekuzzaman, SM; Islam, MM; Chowdhury, SR; Hossain, MS (2016). Heavy metals accumulation in coastal sediments. In Environ. Remed. Tech. Metal-cont. soils. (pp. 21-42 